\title{
METODE ŞI TEHNICI DE EDUCAŢIE FORMALĂ ŞI NON-FORMALĂ A TINERILOR ÎN BISERICĂ
}

\author{
Gabriel Sorescu
}

\begin{abstract}
The Church youth mission involves both their calling from God ,but also educating them in the spirit of the Orthodox faith. In this regard the Church undertakes an extensive work with formal and non formal methods and techniques. Successful action of religious education and training of young people today depends on many factors: the knowledge about young people, applying discerning methods by those in charge of education, the availability of the missionaries, the existence of interested people, a receptive Christian community etc. The present study aims to highlight some of formal and non formal methods and techniques applied in missionary pastoral work with young people in the Church. There are presented advantages and disadvantages of each method and techniques. It also made a brief presentation of the types of young with whom a priest meets in his pastoral activity. All together form a huge part of the action taken by the Church in educating its young members. But this approach allows us to shape the present and future generation of our Orthodox Church.
\end{abstract}

Keywords: mission, methods and techniques of education, receptive Christian community.

Transformările prin care societatea noastră a trecut şi încă trece sunt deosebite. Evenimentele din 1989, apoi integrarea europeană din 2007, au găsit România nepregătită pentru multe provocări, inclusiv în plan religios. Factori economici, culturali, politici, sociali afectează viaţa de zi cu zi a românului, indiferent din ce categorie socială ar face parte. Dacă cei în vârstă au înţeles şi se acomodează unei vieţi în care se luptă pentru medicamente şi reţete compensate, dacă adulţii trăiesc cu nesiguranţa serviciului, cu

PhD Candidate, Faculty of Orthodox Theology, at University of Craiova, Romania. 
zbaterea zilnică pentru procurarea celor necesare, tinerii deschid ochii într-o lume ce se schimbă, se transformă mai repede decât topul melodiilor pe care le-au ascultat până mai ieri.

De fapt cei mai afectaţi sunt tinerii. Familia, şcoala şi credinţa acestora sunt afectate de o criză a valorilor. Ceea ce se observă este faptul că tentaţia străzii, a mondenităţii, a modernităţii „fără limite”, a trăirii clipei fără Dumnezeu, fără Biserică, fără legi constrictive, abundă şi tind să sufoce capacitatea de discernământ a tinerilor noștri.

Există mai multe elemente ce descriu situaţia tineretului român de azi. Ne gândim la factori de natură socio-economică: familia, societatea, în general, dar şi la factori de natură spirituală, factori religioşi.

Familia trece printr-o criză de structură: tot mai mulţi părinţi preferă, cu riscul de a lăsa copiii fără ajutorul lor direct, să plece în alte ţări europene pentru un trai mai bun. Rămași acasă, copiii devin în câţiva ani tineri crescuți fără sprijinul şi educaţia părinţilor lor. Mai mult,

„familia rurală tradiţională cu unitatea ei patriarhală (...) devine la oraş nucleară, cu un mic număr de copii şi părinţi (unul sau cel mult doi). Lipsa unui acoperiş, chiriile ridicate, creşterea cheltuielilor casei absorb timpul vieţii în dauna căutărilor duhovniceşti. Frecvente sunt şi divorţurile din cauza lipsei unor baze solide, cu triste consecinţe asupra dezvoltării copiilor"

care devin în scurt timp tineri şi adulţi debusolaţi.

Relaţia între structurile tradiţionale ale societăţii româneşti, Şcoală, Biserică, Familie, este afectată şi aproape desfiinţată. Părinţii de multe ori nu cunosc unde învaţă copilul lor şi nici cum se numeşte dirigintele. $\mathrm{Cu}$ atât mai puţin numele preotului de a cărui parohie aparţine familia lui, sau ce fel de programe de tineret se dezvoltă dacă se dezvoltă - la biserica din cartier.

Părintele Teofil Tia este de părere că:

${ }^{1}$ Gheorghios D. Metallinos, Parohia - Hristos in mijlocul nostru, Sibiu, Edit. Deisis, 2004, p. 121. 
„putem vorbi şi de un faliment al instituţiilor educative tradiţionale. În familie, educaţia este delegată altor agenţii, mai mult sau mai puţin specializate. Şcoala se rezumă doar la rolul de instituţie ce oferă instrucţie intelectuală, uitând de rolul ei în formarea identităţii personale a tinerilor. Parohia, în afara nevoilor şi problemelor, nu propune tinerilor itinerarii atractive şi convingătoare." 2

La vârsta adolescenţei există o receptivitate maximă pentru noţiunile etice şi religioase. Din păcate, la această vârstă tinerii sunt uşor influenţabili nu numai în bine, ci şi în rău. Iar acest lucru îl vedem şi din faptul că în viaţa Bisericii noastre sunt implicaţi puţini tineri.

Acest lucru este surprins de Înaltpreasfințitul Mitropolit Teofan care spunea: „tinerii din România începutului celui de-al treilea mileniu au diferite atitudini faţă de Biserică. Pentru unii tineri, din păcate puţini la număr, apropierea de Biserică este trăită ca o necesitate a unei vieţi autentice. (..) Majoritatea tinerilor însă, nu au o viaţă religioasă în adevăratul sens al cuvântului."’3

Anumite probleme ale tinerilor fac necesară şi prioritară problema educaţiei lor din punct de vedere religios. Tinerii sunt victime ale propriilor vicii, patimi (libertinaj sexual, relaţii înainte de căsătorie, concubinaj, avorturi - din 1989 până în prezent ${ }^{4}$ în România s-au înregistrat peste 7 milioane de avorturi - alcool, fumat, droguri - în Bucureşti unul din trei tineri a experimentat droguri, iar în marile licee a apărut „,moda” de a fuma marijuana - amintim apoi de violenţă, vagabondaj etc.). Ziarele şi televiziunea prezintă zilnic

${ }^{2}$ Arhim. Teofil Tia, "Elemente de pastorală misionara pentru o societate postideologică”, Alba Iulia, Edit.it. Reîntregirea, 2003, p. 375.

${ }^{3}$ Teofan Savu, Mitropolitul Olteniei, Tinerii, prioritate misionară a Bisericii, în "Biserica în misiune, Patriarhia Română la ceas aniversar, 120 de ani de autocefalie 1885-2005; 80 de ani de patriarhat 1925-2005", volum tipărit cu aprobarea Sfântului Sinod al Biserici Ortodoxe Române, Bucureşti, Edit.it. IBM, 2005, p. 413.

${ }^{4}$ Din perioada 1990 - 2008. Până în prezent numărul avorturilor este mult mai mare. Cf. http://roncea.ro/2010/03/09/cati-copii-au-fost-ucisi-dupa-1990-inromania-7-259-596-info-provita-bucuresti/ 
ştiri despre astfel de lucruri, iar noi le întâlnim pe viu în comunităţi, în şcoli şi în parohiile noastre.

Tinerii sunt afectaţi de o serie de influenţe negative specifice societăţii contemporane. Sfântul Paisie Aghioritul spune că „mulţi sfinţi şi-ar fi dorit să trăiască în vremurile de astăzi pentru a se nevoi", 5 evidenţiind condiţiile grele ale vremurilor contemporane. Pentru tinerii noştri neiniţiaţi în viaţa duhovnicească, aceste influenţe sunt însă de multe ori devastatoare, fie că este vorba de grupurile cu care se asociază, fie de încurajarea unor stiluri de viaţă păcătoase prin chiar legile statului (legalizarea prostituţiei, a homosexualităţii, educaţia sexuală în şcoli, planing-ul familial), fie de mass-media şi de internet.

Dincolo de acestea, observăm dezvoltarea unui spirit anticlericalist. Manipulaţi de spirite neliniştite, tinerii de azi se asociază şi par dornici să-şi ucidă dumnezeii. Cazul Colectiv arată că, fără o ghidare spirituală sănătoasă, tinerii sunt o masă de manevră.

Familia, şcoala, societatea în general au devenit incapabile să mai ofere modele viabile. Conflictul apare în momentul când tânărul realizează că în societatea în care trăieşte valorile s-au inversat. Unii refuză să se implice în activitatea şcolară pe motiv că mulţi dintre colegi, care au bani şi părinţi sus-puşi social sau politic, obţin, fără să înveţe, note mai bune şi au mai mari şanse să reuşească în viaţă cu relaţiile sau prin metode ilegale ${ }^{6}$.

Printre problemele care afectează familia şi tinerii, ca membri ai familiei, Părintele Teofil Tia aminteşte de distrugerea progresivă a ruralului prin urbanizare, de mobilitatea geografică şi ocupaţională ce afectează familiile şi individul în oraşele noastre, precum şi de pragmatism şi profanitate. Tinerii trăiesc într-un mediu lipsit de

\footnotetext{
${ }^{5}$ Cuviosul Paisie Aghioritul, $C u$ durere şi dragoste pentru omul contemporan, Schitul Lacu, Sfântul Munte Athos, Edit.it. Chilia „Buna Vestire”, 2000, p. 126. ${ }^{6}$ La o conferinţă susţinută în Craiova, un participant a oferit un raport în urma unui foto-voices la care au participat un număr de tineri. Un tânăr şi-a ales ca imagine reprezentativă un BMW de ultimă generaţie. La comentariu, el a spus că simte că această maşină îl defineşte, o vrea, deşi nu crEdit.e că doar prin muncă cinstită va reuşi să o obţină.
} 


\section{$15^{\text {th }}$ International Symposium on Science, Theology and Arts}

repere. De aici, lipsa de implicare ce determină o alienare a atitudinii lor faţă de viaţă. ,Tineretul de azi trăieşte din multe puncte de vedere o suspendare în prezent. Mulţi tineri preferă să-şi privească propriul viitor ca rezultatul unor circumstanţe externe şi inevitabile, ale căror dinamici interioare scapă posibilităţilor lor individuale de orientare, de control şi de intervenţie" "7. Acest fapt oferă o explicației pentru refugiul lor în falsele credinţe: superstiţii, destine, ghicit, horoscop etc.

Ca urmare a lipsei de modele, precum şi a influenţelor nocive de care aminteam, o parte din tineri au un sistem de valori (bani, putere, egoism etc.) total diferit de cel propus de către Biserică, îşi întrebuinţează timpul liber într-un mod nociv, greşit (discotecă, bar, chefuri, beţii etc.), caută să se realizeze profesional în afara ţării ${ }^{8}$ sau prim metode ilegale, iar de aici rezultă lipsa responsabilizării lor sociale.

Amintim un alt aspect: integrarea europeană. Părintele Gheorghios Metallinos, subliniind specificul ortodox răsăritean - în care ne includem şi noi, românii ortodocşi - afirmă ca o problemă din ce în ce mai acută este „europenizarea omului”, transformarea lui din ce în ce mai mult în homo economicus, în sensul convertirii lui într-o perspectivă materialistă, neduhovnicească. Recunoaştem la tinerii de azi o tendinţă din ce în ce mai crescândă spre acest model al omului european ${ }^{9}$.

Şcoala pare să nu fie străină de această transformare a tinerilor noştri. De fapt, ,deseori ei sunt inundaţi cu teorii agnostice şi materialiste. Ei pleacă de la orele de curs cu o singură convingere: că adevărul este relativ, iar virtuţile imposibile şi nefolositoare"10. De aici, se ajunge la îndoială şi relativism.

\footnotetext{
${ }^{7}$ Arhim. Teofil Tia, op. cit., p. 370.

${ }^{8}$ Din totalul - oficial de 2.3 milioane de emigranţi români, 18 procente sunt cu studii superioare. Cf. http://www.buzznews.ro/143417-record-sumbru-romaniaare-cei-mai-multi-emigranti-cu-studii-superioare-cati-au-plecat-in-ultimii-25de-ani/.

${ }^{9}$ Gheorghios D. Metallinos, op. cit., p. 126.

10 Mitropolit Emilianos Timiadis, Preot, parohie, înnoire, Bucureşti, Edit. Sophia, 2001, p. 98-99.
} 
Nici parohia nu reuşeşte să îşi îndeplinească întru totul rolul. Dacă familia este celula de bază a societăţii, parohia este unitatea de bază a Bisericii. Comunităţile rurale trăiesc o dezagregare fără precedent: numărul decedaţilor este de câteva ori mai mare decât al celor ce se nasc, iar tinerii şi adulţii pleacă din ţară pentru o bucată de pâine. Urbanizarea a atras şi va atrage şi mai mult după sine transformări şi din punct de vedere al structurii de formă şi de fond a parohiei. Numărul foarte mare de familii arondate unor parohii de la oraș, face imposibilă păstorirea cu eficiență a enoriașilor. Un alt aspect este dezagregarea unităţii parohiale. Există parohii unde rolul laicilor este minimizat astfel încât nu putem vorbi nici măcar de existenţa consiliului parohial sau a comitetului parohial, cu atât mai puțin de implicarea tinerilor în structuri misionare.

Din punct de vedere religios, nu de puține ori se ântâmplă ca tinerii să constate o scădere a interesului faţă de Biserică la părinţii lor, la bunicii lor, la vecinii lor, care au, în unele cazuri, reacţii de dezaprobare atunci când tânărul se apropie de Dumnezeu şi de Biserică. Tinerii nu au un model de urmat în familie, în şcoală sau în societate. Este normal deci ca şi la ei să se observe, să se transmită acelaşi dezinteres.

Aici suntem datori să amintim, printre cauzele ce au determinat această stare a lucrurilor, şi aceea a educaţiei comuniste. Aceasta s-a impus, din păcate, pe două planuri: laical şi clerical.

Din perspectiva laicilor, tinerii de azi care doresc să se implice în viaţa Bisericii duc un stil de viaţă pe care părinţii lor, după 50 de ani de comunism, nu-l mai cunosc sau nu îl cunosc deloc. Generaţia adulţilor de astăzi, născuţi şi crescuţi în epoca ateistă, nu posedă o cultură religioasă. De multe ori părinţii tind să oprească iniţiativele copiilor lor de implicare în viaţa Bisericii. Motivaţiile lor scot în evidenţă exact necunoaşterea: „Ce cauţi la biserică? Acolo se duc doar moşii şi babele.”, „Ce-ţi dă ţie Dumnezeu?”, „Nu cumva vrei să te călugăreşti?".

Din punct de vedere clerical, situaţia este determinată de faptul că, dacă Biserica înainte de 1945 era implicată în toate structurile educaţionale, în perioada comunistă a fost nevoită să-şi restrângă la minim activitatea misionară, rezultând comunităţi 


\section{$15^{\text {th }}$ International Symposium on Science, Theology and Arts}

închise $^{11}$. Aceasta s-a redus la o misiune intra murros, care este o formă minimă de misiune internă. Revoluţia din 1989 şi deschiderea generată de aceasta, a găsit Biserica nepregătită pentru a prelua vechile structuri misionare. $\mathrm{Cu}$ toate că religia se predă în şcoli, cu toate că în unităţile bugetare avem asistenţă religioasă, mulți preoţi privesc puţin ciudat tinerii care, într-un număr din ce în ce mai mare, intră pe uşile bisericilor lor cerând sfat sau spovedanie.

Problemele cu care tinerii se confruntă în mediul lor cultural „subteran”, ascuns vederii noastre, a celor din Biserică, pun în situaţie dificilă pe unii preoţi care a fost şcoliţi şi educaţi în perioada când aceste probleme, fie nu existau, fie era interzis ca ele să fie abordate. Amintim apoi despre opinii ale anumitor clerici, spuse pe la colţuri, cum că atenţia acordată tinerilor care calcă pragul bisericii ar fi „pierdere de timp” şi că „nu aduce niciun câştig”, sau că acţiunile care-i vizează pe tineri ar semăna a sectarism şi ar fi, chipurile, împotriva modului de misiune practicat de către Sfinţii Părinţi. Toate acestea nu fac decât să paralizeze iniţiativele, uneori timide şi rare, ale preoţilor care găsesc în rândul tinerilor un mediu de misiune propice.

Există însă oameni care văd misiunea Bisericii cu tinerii şi pastoraţia acestora ca de actualitate stringentă. Iată ce spune în acest sens Mitropolitul Teofan: „Evocarea faptului că tineretul este şi trebuie să constituie prioritatea misionară a Bisericii nu are nevoie de prea multe argumente. Acest adevăr este aplicabil în orice instituţie, în orice comunitate umană şi cu atât mai mult în Biserică" ${ }^{\prime 2}$.

Patriarhul Daniel, în acest sens, a precizat faptul că „este necesară o lucrare pastorală a Bisericii, mai intensă şi mai vastă, de sfătuire a tinerilor care urmează să se căsătorească, precum şi a familiilor tinere" 13 . Şi acesta este doar un aspect al edificiului care se cere consolidat. În alt context, Părintele Patriarh a afirmat:

\footnotetext{
${ }^{11}$ Anastasie, Arhiepsicop al Tiranei şi al întregii Albanii, Misiune pe urmele lui Hristos, Sibiu, Edit. Andreiana, 2013, p. 49.

${ }^{12}$ Teofan Savu, Mitropolitul Olteniei, Tinerii, ..., p. 413.

${ }^{13}$ Daniel, Mitropolitul Moldovei şi Bucovinei, Familia creştină - „Biserica de acasă, în „Familia creştină azi”, Iaşi, Edit. Trinitas, 1995, p. 6.
} 
„cooperarea dintre Biserică-Şcoală-Familie se va intensifica prin activităţi şi proiecte concrete, cu scopul unei bune desfăşurări a actului educaţional. În cadrul acestui proces, părinţii elevilor, profesorii de religie şi preoţii din parohii trebuie să coopereze şi să urmărească acelaşi ţel: educarea şi formarea copiilor pentru viaţă şi pentru societate, dar şi pentru Împărăţia lui Dumnezeu, adică pentru a trăi cu demnitate în familie şi în societate, dar şi în lumina iubirii eterne a lui Dumnezeu" $" 14$.

Misiunea Bisericii în rândul tinerilor presupune atât chemarea lor la Dumnezeu, cât şi educarea lor în spiritul credinţei ortodoxe. În acest sens, Biserica întreprinde o amplă activitate de educare prin şcoli, seminarii liceale, facultăţi de teologie şi parohii.

Faptul că anul 2016 a fost declarat Anul omagial al educaţiei religioase a tineretului creştin ortodox, este un motiv să sperăm că misiunea cu tinerii va avea un trend ascendent cu efecte benefice.

Iată de ce este necesară educaţia tinerilor în spiritul credinţei creştin-ortodoxe româneşti. Şi cred că cea mai bună sugestie, referitor la metoda de a-i atrage şi a-i educa pe tineri, indiferent că e formal sau non-formal, clasic sau modern, ne-a sugerat-o Sfântul Apostol Pavel:

„Cu iudeii am fost ca un iudeu, ca să dobândesc pe iudei; cu cei de sub lege, ca unul de sub lege, deşi eu nu sunt sub lege, ca să dobândesc pe cei de sub lege; cu cei ce n-au Legea, m-am făcut ca unul fără lege, deşi nu sunt fără Legea lui Dumnezeu, ci având Legea lui Hristos, ca să dobândesc pe cei ce n-au Legea; cu cei slabi m-am făcut slab, ca pe cei slabi să-i dobândesc; tuturor toate m-am făcut, ca, în orice chip, să mântuiesc pe unii” (I Cor. 9, 20-22).

\footnotetext{
${ }^{14}$ Daniel, Patriarhul Bisericii Ortodoxe Române, Cooperarea dintre parohie şi şcoală în contextul misiunii Bisericii şi al responsabilităţii pentru generaţiile viitoare", în Relaţia dintre parohie şi Şcoală în viaţa şi misiunea Bisericii din contextul actual, Volum coordonat de Adrian Lemeni şi Pr. David Pestroiu, Bucureşti, Edit. Basilica, 2015, p. 16.
} 


\section{Metode formale şi non-formale de educaţie a tinerilor în Biserică}

Orice acţiune întreprinsă de om este posibilă datorită aplicării unor căi de rezolvare şi a unor mijloace specifice. Dicţionarul Explicativ al Limbii Române defineşte metoda ca fiind un „procedeu sau ansamblu de procedee folosite în realizarea unui scop" "15. Aşadar, metoda este calea prin care ne atingem obiectivele. Din perspectiva profesorilor, „metoda didactică este un plan de acţiune conceput pentru transmiterea cunoştinţelor şi formarea competenţelor specifice" ${ }^{\prime \prime}$.

Metodele non-formale sunt numite aşa datorită faptului că ele depăşesc cadrul formal dat de mediul sau regulile unei discuţii (de obicei şcoala sau biserica). Noutatea - şi de aici eficienţa lor - constă în aceea că pot fi aplicate oriunde şi ori de câte ori se oferă ocazia. Sunt interactive ${ }^{17}$, adică presupun implicarea, atât a educatorului creştin - preot sau misionar laic -, cât şi a celui educat, şi sunt apanajul unei misiuni extra murros, fiind de aceea întâlnite la cei care activează mai mult în afara bisericii.

Dintre metodele de educare religioasă a tinerilor amintim: prelegerea, conversaţia, povestirea, lectura, discuţia colectivă, problematizarea, explicaţia, simularea, cuvântul cheie, demonstraţia, exerciţiul, activitatea practică şi lucrul în grup.

1. Prelegerea sau conferinţa este metoda în care un ca moderator (preot sau tânăr responsabil) prezintă tema pregătită dinainte în faţa întregului grup ${ }^{18}$. Prelegerea are avantajul că expune o temă deja pregătită, argumentată. Dezavantajele acestei metode se referă la monotonia provocată de un singur vorbitor şi lipsa de

${ }^{15}$ Dicţionar Explicativ al Limbii Române, ed. a II a, Bucureşti, Edit. Univers Enciclopedic, 1996, p. 626.

${ }^{16}$ Mihai Diaconu; Prof.univ.dr. Ioan Jinga coordonatori, Pedagogie, București, Edit. ASE, 2004, p. 256.

${ }^{17}$ În Programa catehetică pentru parohii, sunt prezentate 16 metode interactive de prezentare a conţinuturilor şi 11 metode de evaluare a activităţilor de educare a tinerilor creştini, Iaşi, Edit. Doxologia, 2006, p. 25-36.

${ }^{18}$ Fundaţia LIFE, Dezvoltarea aptitudinilor.., în Pachetul.., (CD) p. 220. 
intervenţie a auditorilor în decursul expunerii. Aceştia nu pot interveni să îşi spună părerea „la cald”, ci eventual la final, după ce sau tras concluziile.

2. Conversaţia este un dialog ce are loc între educator, moderator şi tineri, prin care se stimulează şi se dirijează educarea acestora $^{19}$. Poate fi de două feluri: conversaţie euristică şi conversaţie catehetică.

Conversaţia euristică presupune o succesiune de întrebări adresate de către moderator în alternanţă cu răspunsurile date de către tineri, prin care se urmăreşte realizarea unor asociaţii între informaţiile pe care aceştia le deţin, astfel încât să ajungă la descoperirea unor date noi.

Conversaţia catehetică este binecunoscută de către absolvenţii de seminarii şi facultăţi de teologie, fiind structura unei cateheze. Ea presupune expunerea temei sub forma unor întrebări şi răspunsuri, după o structură logico-psihologică prestabilită, care include următoarele etape: pregătirea aperceptivă, anunţarea temei, tratarea temei, recapitularea, asocierea, generalizarea şi aplicarea ${ }^{20}$.

Avantajele acestei metode sunt date de interacţiunea dintre vorbitor şi auditori. Dezavantajele se referă în special la concentrarea pe un subiect dat şi eventual la lipsa de interes a auditorilor care conduce la lipsa de dialog.

$\mathrm{Ca}$ o formă particulară de conversaţie avem metoda punte. Acesta presupune ca moderatorul să dezvolte o discuţie aparent întâmplătoare cu tinerii, pornind de la un subiect important pentru unul sau mai mulți dintre ei. Prin întrebări bine gândite, preotul sau moderatorul conduce discuţia spre subiectul care doreşte să fie discutat de fapt, plecând de la ceva aparent banal.

3. Povestirea este metoda în care moderatorul prezintă întâmplări reale, file, fragmente de opere literare. Poate fi folosită în orice moment al activităţii, având rolul de a sensibiliza auditoriul şi

\footnotetext{
${ }^{19}$ Ioan Nicola, Tratat de pedagogie şcolară, Bucureşti, Edit. Aramis, 2003, p. 378.

${ }^{20}$ Pr. Vasile Gordon, Introducere în catehetica ortodoxă, Bucureşti, Edit. Sophia, 2004, p. 121-123.
} 
de a-1 face mai receptiv la un anumit subiect, de a ilustra concret anumite informaţii pur teoretice. Se foloseşte mai rar singură, fiind mai degrabă apanajul unei argumentări.

4. Lectura. Tinerii pot lectura în grup sau individual fragmente din Sfânta Scriptură, din Vieţile Sfinţilor, din Catehismul Bisericii Ortodoxe, sau din alte cărţi moralizatoare. Lectura poate fi folosită ca punct de plecare pentru dezbaterea unei teme, poate avea ca scop înţelegerea unui text sau ilustrarea unei învăţături creştine. Un mod incitant de utilizare a acestei metode este aplicare tehnicii cuvântului cheie.

5. Discuţia colectivă ,se prezintă ca un schimb reciproc, organizat şi constructiv de informaţii, impresii, păreri, aprecieri critice, propuneri, axat în jurul unui subiect luat în studiu, al examinării unui exemplu, al unui fapt" ${ }^{\prime 2}$. Este folosită mai mult cu ocazia vizitelor pastorale sau după încheierea unui eveniment când încă se stă de vorbă pe marginea subiectului.

6. Problematizarea constă în crearea unor stări aparent conflictuale, contradictorii, prin confruntarea dintre experienţa anterioară a tinerilor tăi cu un element de noutate în faţa căruia datele vechi se dovedesc insuficiente. Se creează astfel o situaţie problemă la care tinerii trebuie să propună soluţii.

7. Explicaţia constă în dezvăluirea unor date noi pe baza unei argumentaţii. Se enunţă o definiţie, o regulă, un principiu sau se prezintă un fenomen, o situaţie, iar apoi se analizează exemple şi argumente.

8. Metoda simulării (jocul de rol) presupune să fie prezentat subiectul de dezbătut sub forma unei dramatizări. Pentru aceasta este nevoie de voluntari care să joace diferite roluri: pozitive şi negative etc. Se pot conferi roluri de „observatori” celorlalţi care să urmărească atent un personaj sau o situaţie apoi să discute despre acestea. Se pot simula fenomene, activităţi, situaţii, fapte. Aici includem jocurile şi învăţarea prin dramatizare. Această metodă ajută tinerii să conştientizeze anumite soluţii la probleme, să evalueze atitudini, deprinderi, informaţii, să se instruiască în anumite domenii.

${ }^{21}$ Ioan Cerghit ş.a., Didactica, 1994, p. 85. 
Jucarea unui rol urmăreşte realizarea anumitor scopuri. Moderatorul explică rolurile personajelor şi, dacă este necesar, timpul şi locul unde se desfăşoară acţiunea.

Este indicat să se permită „actorilor” să evolueze dincolo de rol. Pentru o mai mare implicare a celorlalţi membrii ai grupului se pot delega sarcini de „observatori”. După joc, moderatorul va rezerva timp pentru procesarea informaţiei. Discuţia ,de după” este bine să-i implice pe toţi participanţii.

Exemple de întrebări:

- Cum au jucat ,actorii”’?

- În ce măsură şi-a atins piesa scopul anunţat?

- Ce idei noi am aflat din acest joc de rol?

- Ce aţi învăţat din ceea ce s-a prezentat?

- Cum aplicăm cele învăţate?

9. Cuvântul cheie ${ }^{22}$ presupune ca cineva din grupul de tineri să citească un text din Sfânta Scriptură, timp în care ceilalţi ascultă cu atenţie şi îşi aleg, fiecare, un cuvânt cheie care le-a plăcut. După ce toţi tinerii prezintă ce au ales, se citeşte iar textul (preferabil de către altcineva), fiind rugaţi să privească textul prin prisma cuvântului cheie ales de către ei.

După un moment de reflecţie, tinerii sunt rugaţi să interpreteze pe rând textul. În final, tinerilor li se va adresa întrebarea: „Ce sens dă vieţii tale cuvântul ales?". Textul este citit a treia oară de către un alt tânăr, apoi fiecare îşi prezintă răspunsul. Ca un ultim punct, preotul prezintă concluzia generală, evidenţiind învă-ţătura de bază relevată de textul citit.

10. Demonstraţia constă în prezentarea unor obiecte, acţiuni sau reproduceri ale acestora în scopul dobândirii de informaţii despre acestea. Concret, poate fi demonstrat un comportament sau un mod de a acţiona, pot fi prezentate imagini, hărţi, planşe, diapozitive,

${ }^{22}$ Pr. Daniel Bulai, op. cit., p. 99-100. 
filme despre realităţi care nu pot fi studiate de către tineri nemijlocit, „pe viu”.

11. Exerciţiul este metoda care constă în „efectuarea conştientă şi repetată a unor acţiuni în scopul formării de priceperi şi deprinderi practice şi intelectuale, dezvoltării unor capacităţi şi aptitudini, consolidării cunoştinţelor dobândite" ${ }^{, 23}$. Tinerilor li se prezintă structura şi scopul exerciţ̧iului, li se explică şi demonstrează în prealabil şi se creează o situaţie de exersare cât mai variată. De exemplu, rugăciunea, închinarea sau învăţarea unor cântări bisericeşti.

12. Activităţile practice sau Atelierul se referă la învăţarea prin propria acţiune. În acest caz, tinerii sunt rugaţi să întocmească un puzzle sub forma unui om, să deseneze o corabie, să inventeze un joc etc. La final, moderatorul îi solicită pe tineri să realizeze diverse asocieri: corpul uman - comunitatea bisericii; corabia - clădirea bisericii etc. Metoda dezvoltă foarte mult creativitatea şi lucrul în echipă.

13. Lucrul în grup constă în împărţirea tinerilor pe echipe care au diverse sarcini de rezolvat. Această metodă stimulează interacţiunea între membrii grupului, facilitează exprimarea opiniilor, îi confruntă pe tineri cu situaţii de cooperare, competiţie şi chiar conflict, creând un climat favorabil dobândirii de către aceştia a unor abilităţi de comunicare, negociere, rezolvare a conflictelor, muncă în echipă.

\section{Tehnici de lucru cu tinerii creştini}

Tehnicile sunt definite ca fiind ,totalitatea instrumentelor şi procedeelor de lucru, cu ajutorul cărora se execută o lucrare"24. Există foarte multe tehnici de lucru aplicabile într-un grup de tineri. Unele surse ${ }^{25}$ clasifică aceste tehnici în mai multe categorii: individuale, de grup, de învăţare, de evaluare etc.

\footnotetext{
${ }^{23}$ Ioan Cerghit, op. cit., p. 90.

${ }^{24}$ Daniel Bulai, op.cit., p. 97.

${ }^{25}$ Fundaţia LIFE, Dezvoltarea aptitudinilor....... în Pachetul... (CD) p. 193-194.
} 
Tehnici individuale pot fi: vizita, telefonul, scrisoarea (e-mailul), interviul, auto-instruirea, calculatorul, discuţia particulară.

Tehnici de grup în lucrarea de educare a tinerilor creștini sunt: atelierul, discuţiile, excursiile, drumeţiile, jocul de rol, brainstorming, grupurile mici, studiul de caz, materiale video (diapozitive, filme, hărţi), tablă, fleep-chart, camping, concursuri, jocuri, site-ul sau blogul parohiei ${ }^{26}$ etc.

În funcţie de activităţile desfăşurate în educarea tinerilor creştini se pot aplica una sau mai multe tipuri de tehnici. Există anumite tehnici specifice activităţilor catehetice, altele sunt specifice activităţilor recreative, altele specifice activităţilor culturale, întâlnirilor de rugăciune etc. Dintre acestea amintim: tehnica brainstorming, lucrul pe grupuri mici, „Round robin”, activități recreative (jocuri),

\section{Tehnica asaltului de idei - Brainstorming-ul ${ }^{27}$}

Este o varianta a discuţiei în grup ${ }^{28}$, folosită în scopul de a înlătura tensiunea din grup, când se urmăreşte să se „spargă gheaţa”, pentru a oferi tuturor şansa să-şi expună opinia, pentru a transforma ideile individuale în idei de grup, pentru a oferi un material în vederea clarificării unui scop, pentru evaluarea unei acţiuni, pentru aflarea unor soluţii, pentru a înviora atmosfera.

Când se aplică această tehnică, se prezintă întâi cele şase reguli ale brainstorming-ului

1. Spune ideea cu voce tare fără a aştepta aprecierea ei.

2. Ideile îndrăznețe sunt acceptate, toate ideile sunt acceptate aici.

${ }^{26}$ Dată fiind amploarea pe care a luat-o spaţiul virtual considerăm imperios necesar ca Biserica sub orice formă să fie prezentă cât mai mult în ,,areopagul mEdit.iatic". A se vedea în acest sens lucrarea domnului Gheorghe-Cristian Popa, Preotul misionar în areopagul meditatic. Mijloace moderne de comunicare în pastoraţia ortodoxă, București, Edit. Cuvântul Vieţii a Mitropoliei Munteniei şi Dobrogei, 2013.

${ }^{27}$ Fundaţia LIFE, Dezvoltarea aptitudinilor..., în Pachetul... (CD) p. 202/203.

${ }^{28}$ Diaconu et. al., op. cit., p. 309. 
3. Poţi spune o idee care a mai fost spusă, dacă adaugi ceva la ea sau o completezi.

4. Stabileşte o limită de timp. Cinci, zece minute sunt de ajuns să aduni idei destule.

5. Fii scurt, nu explica sau aprofunda ideile.

6. Nu evalua ideile în timpul tehnicii cu niciun fel de mimică, limbaj non-verbal sau verbal.

Moderatorul anunţă tema pentru care trebuie să se susţină brainstorming-ul. Se pregăteşte din timp coală şi marker pentru notarea ideilor, alegând eventual un secretar care să le noteze. Se reamintesc participanţilor regulile şi timpul apoi se dă startul. Dacă nu sunt idei, moderatorul dă un exemplu pentru început. Dacă ideile vin şi timpul s-a terminat, se poate prelungi. Dacă nu sunt idei, timpul se poate reduce.

La final, moderatorul:

- laudă intervenţiile şi mulţumeşte tuturor;

- începe explicarea şi întreabă dacă anumite idei sunt neclarificate;

- începe evaluarea astfel:

1. elimină ideile nefolositoare, cu acceptul grupului;

2. subliniază, tot cu acceptul grupului, două sau trei idei importante;

3. critică ideile greşite, menţionând că respingi ideea, nu persoana;

\section{Grupurile mici ${ }^{29}$}

Unele materiale de pregătire a moderatorilor numesc grupurile mici, alcătuite din 5 - 6 persoane, formate din membrii grupului mare sub numele ,grupuri Buzz"30.

${ }^{29}$ Siluana Vlad, Gabriel Sorescu, Tinerii şi Biserica în zilele noastre, Ed.a II-a adăugită şi îmbunătăţită, Craiova, Edit. Mitropolia Olteniei, 2007, p. 20-25.

${ }^{30}$ Handaut-ul ,Procesarea”, în „Fundaţia Life-Tineret”, Caietul..., p. 71. 
Această tehnică, utilizată atât în instruire, educare cât şi în evaluare, este foarte eficientă prin numărul mic de membrii care alcătuiesc grupurile mici. În cadrul unui seminar, rolul grupurilor mici este de a rezolva o sarcină, de a răspunde la întrebările adresate de către moderatorul activităţii. Timpul de rezolvare a sarcinii este de la 15 la 30 minute.

Împărţirea tinerilor este un prilej de manifestare a originalităţii moderatorului. Iată câteva sugestii de formare a grupurilor mici:

- după prima literă a numelui, dacă există un număr destul de egal de tineri al căror nume începe cu litera sau literele propuse de către moderator;

- după numărul de tineri şi numărând din 4 în 4, sau din 5 în 5, dacă grupul este mare;

- după luna de naştere, numărând-i după ce s-au aranjat pe criteriul înălţimii, sau al mărimii încălţămintei etc.

Formarea grupurilor mici poate lua aspectul unui joc de animare, adăugând diferite reguli: „,̂mpărţiţi-vă după înălţime, fără să vorbiţi între voi." ş.a.

Rezolvarea sarcinilor în grupurile mici presupune stabilirea în prealabil, de către moderator a unor reguli clare: toţi tinerii din grupul mic au dreptul să-şi exprime liber opinia; ceea ce se discută este prezentat ca fiind opinia grupului, nu a persoanei; cel care prezintă opinia grupului - ales dintre membrii, altul decât cel care a fost anterior - prezintă toate opiniile, fără a menţiona pe cel care a făcut afirmaţiile.După îndeplinirea sarcinilor, grupurile mici se regrupează formând grupul mare.

\section{3. „Round robin”}

Este atât o tehnică de animare, cât şi de evaluare. Avantajul acestei tehnici este dat de faptul că toţi membrii grupului mare, pe rând, vor răspunde la întrebarea moderatorului acţiunii.

După ce se adresează întrebarea tinerilor grupului, li se dă un timp de gândire ( $2-3$ minute). În acest timp participanţii pot să-şi noteze răspunsurile pe o hârtie. Este numit un secretar care să noteze răspunsurile, fără a nota ceea ce se repetă. Apoi, pe rând, tinerii răspund la întrebare. După ce toţi răspund, se evaluează prin discuţii 


\section{$15^{\text {th }}$ International Symposium on Science, Theology and Arts}

şi se desprind concluziile.

Întrebările pot fi: de evaluare (Ce v-a plăcut la ultimul seminar?) sau de lucru (Cum răspundeţi la întrebarea....?).

\section{Activităţi recreative (jocuri)}

Activităţile recreative sunt de mai multe feluri: de spart gheaţa (de acomodare), de cunoaştere, de consolidare a echipei, de simulare (jocul de rol). Unele jocuri urmăresc doar să ofere un moment recreativ membrilor tineri, altele urmăresc şi să le transmită, prin practică, anumite informaţii. De aceea, se cere ca un joc să aibă reguli clare, precise, care să fie prezentate explicit participanţilor. De asemenea, obiectivele activităţii trebuiesc menţionate participanţilor.

Rolurile se pot împărţi voluntarilor sau anumitor tineri capabili. Odată început jocul, conducătorul activităţii îşi rezervă rolul de moderator. Implicare sa, minimă, presupune intervenţia în buna desfăşurare a jocului. Celor care nu sunt implicaţi activ, e bine să li se ofere roluri de observatori.

La finalul activităţii se rezervă timp pentru procesarea celor învăţate din activitate, provocată prin adresarea de întrebări gradate, pe baza cărora se pot identifica şase faze ale procesăriii ${ }^{31}$ :

1. Cum vă simţiţi după acest joc?

2. Ce s-a întâmplat în timpul desfăşurării jocului? Care au fost momentele principale? Ce rol ai avut?

3. Despre ce credeţi că este vorba în acest joc?

4. Ce legătură este între ce s-a jucat şi realitate?

5. Ce ar fi fost dacă......?

6. Ce ai învăţat din acest joc?

\section{Foto voices}

Este o tehnică foarte atrăgătoare cu un grad major de implicabilitate. Cei mai mulți tineri au telefoane cu care pot face poze. De comun acord, se alege o temă pentru dezbatere: Biserică, om, viaţă, lumină, eu - despre mine, aproapele meu ş.a. Participanţii sunt rugaţi ca pe parcursul unei zile sau al unei săptămâni să facă o

${ }^{31}$ Handaut-ul „Procesarea”, în „Fundaţia Life-Tineret”, Caietul..., p. 72. 
poză care să reprezinte cel mai bine tema propusă. La întâlnirea lor, moderatorul va ruga tinerii să expună pozele şi să le comenteze: De ce ai ales această poză? Ce îţi sugerează? Ce mesaj transmite?

După prezentarea tuturor, coordonatorul solicită tinerilor să premieze cea mai bună poză şi să-şi spună părerile.

\section{Concluzii}

Metode şi tehnici de lucru formale şi non-formale prezentate cu aplicabilitate la educaţia religioasă a tinerilor au fost utilizate deja cu succes în diferite parohii şi organizaţii de tineret din Arhiepiscopia Craiovei.

Lucrul cu grupurile de tineri reprezintă, de fapt o pastoraţie particularizată la nevoile şi profilul specific unei anumite categorii de enoriaşi. Activităţile mai puţin formale, petrecerea în mod regulat a timpului într-un astfel de cadru al Bisericii au rolul de a traduce Evanghelia pe limba tinerilor, de a-i apropia de Hristos, finalitate pe care trebuie să o avem permanent în vedere.

În adevăr, aşa cum nu există Biserică fără episcop, după cum afirmă Sfântul Ciprian, aşa nu poate exista educaţie creştină fără un educator. De acest educator, cleric sau laic, de disponibilitatea, implicarea, pregătirea şi calitatea sa intelectuală, sufletească şi duhovnicească depinde succesul educaţiei tinerilor şi prin aceasta garantarea că generaţia viitoare va fi o generaţie care să aprecieze Biserica şi eforturile duse de către clericii şi laicii implicaţi în buna desfăşurare a activităţilor ei şi, mai mult decât atât, că aceşti tineri vor fi mădulare vii şi lucrătoare ale Bisericii lui Hristos. 


\section{Bibliografie}

1. Bulai, Daniel, Tânăr între tineri, Ghid de formare pentru animatori, Centrul Diecezan pentru pastoraţia tinerilor, București, Arhidioceza Romano-Catolică de Bucureşti, 1999.

2. Cerghit, Ioan, Didactica, Bucureşti, Edit. Didactică și Pedagogică, 1994.

3. Ciobotea, Daniel, „Cooperarea dintre parohie şi şcoală în contextul misiunii Bisericii şi al responsabilităţii pentru generaţiile viitoare.”, în Relaţia dintre parohie şi Şcoală în viaţa şi misiunea Bisericii din contextul actual, volum coordonat de Adrian Lemeni şi David Pestroiu, Bucureşti, Ed. Basilica a Patriarhiei Române, 2015, p. 13-16.

4. Clair, Barry St., Conducere !, București, Societatea Misionară Română, 1991.

5. Diaconu, Mihai şi Jinga, Ioan coordonatori, Pedagogie, București, Edit. ASE, 2004.

6. Ferreol, Gilles., Dicţionar de Sociologie, trad. de Lia Decei și Radu Garmacea, Bucureşti, Edit. Polirom, 1998.

7. Fundaţia Life Tineret, Caiet de lucru al cursului „Metode creative folosite in activităţile de tineret, Oradea, 2004.

8. Fundaţia Life, Dezvoltarea aptitudinilor lucrătorilor comunitari, Manual de facilitare comunitară în. „Pachetul educaţional al animatorului de tineret", (C.D.) f.a.

9. Fundaţia Noi Orizonturi, Cum să începi un club Kaizen?, Ghid pentru dezvoltarea unui club de tineret, bazat pe educatia în serviciul comunităţii, Lupeni, s.a.,

10. Fundaţia pentru Dezvoltarea Societăţii Civile, Departamentul de Instruire şi Consultanţă, Managementul voluntarilor, suport de curs, Craiova, 2002

11. Gordon, Vasile Introducere în catehetica ortodoxă, Edit. Sophia, Bucureşti, 2004.

12. Lynn, David, Schiţe de discuţie, traducere Tabita Cernica, Edit. Noua Speranţă, 2001.

13. Nicola, Ioan, Tratat de pedagogie şcolară, Bucureşti, Edit. Aramis, 2003

14. Cuviosul Paisie Aghioritul, $\mathrm{Cu}$ durere şi dragoste pentru omul contemporan, Schitul Lacu, Sfântul Munte Athos Edit. Chilia „Buna Vestire", 2000.

15. *** Patericul egiptean, Alba Iulia, Edit. Reîntregirea, 1990. 
16. Popa, Gheorghe Cristian, Preotul misionar în areopagul mediatic, mijloace moderne de comunicare in pastorația ortodoxă, București, Edit. Cuvântul Vieţii a Mitropoliei Munteniei şi Dobrogei, 2013.

17. Savu, Teofan, Tinerii, prioritate misionara a Bisericii, în „Biserica în misiune, Patriarhia Română la ceas aniversar, 120 de ani de autocefalie 1885-2005; 80 de ani de patriarhat 1925-2005", volum tipărit cu aprobarea Sfântului Sinod al Biserici Ortodoxe Române, Bucureşti, Edit. Institutului Biblic și de Misiune al Bisericii Ortodoxe Române, 2005, p. 413-424.

18. Spiliotis, George, Părinţii duhovnici şi copii. Educaţia tinerilor în conformitate cu învăţătura Sfinţilor Părinţi ai Bisericii noastre, trad. de Ilioniu Georgeta-Mariana, Bucureşti, Edit. Cartea Ortodoxă, Edit. Egumeniţa.

19. Teofil, Teofil, Elemente de pastorală misionară pentru o societate postideologică, Alba Iulia, Edit. Reîntregirea, 2003.

20. Timiadis, Emilianos, Preot, parohie, innoire, trad. din limba engleza de Paul Brusanowski, Bucureşti, Edit. Sophia, 2001.

21. Vlad, Siluana, Sorescu, Gabriel, Tinerii şi Biserica în zilele noastre, ed. II-a adăugită şi îmbunătăţită, Craiova, Edit. Mitropoliei Olteniei, 2007.

22. Yaconelli, Mike și Koenigsaecker, Scott, Fă-i să vorbească !, traducere Fundația Creștină Noua Speranţă, Timişoara, Edit. Noua Speranţă, 2001.

\section{Resurse web}

- $\quad$ http://goarch.org/en/archdiocese/departments/youth/youthworkers/ (accesat 10 martie 2006).

- $\quad$ http://goarch.org/en/archdiocese/departments/youth/youthworker/ (accesat la 5 aprilie 2006).

- http://yya.oca.org/youth/ocayouth.asp, (accesat la 20 martie 2006).

- http://www.buzznews.ro/143417-record-sumbru-romania-are-cei-maimulti-emigranti-cu-studii-superioare-cati-au-plecat-in-ultimii-25-deani/ (accesat la 27 martie 2016).

- $\quad$ http://roncea.ro/2010/03/09/cati-copii-au-fost-ucisi-dupa-1990-inromania-7-259-596-info-provita-bucuresti// (accesat la 20 martie 2016). 